\title{
Investigation of Antimicrobial Susceptibility in Enterobacteriaceae Species Isolated From Blood Cultures
}

Öz

Kan dolassımı enfeksiyonları en sık karssılașılan invaziv enfeksiyonlardandır. Bu calıșmada, kan kültürlerinden izole edilen Enterobacteriaceae türlerinin tanımlanması ve antimikrobiyal duyarlılık oranlarının araştırılması amaçlanmıştır.

Haziran 2017-Eylül 2019 tarihleri arasında yatan hastalardan gönderilen kan kültürü örneklerinden izole edilen Enterobacteriaceae üyeleri retrospektif olarak incelenmistir. BacT/Alert ${ }^{\circledR} 3 D$ (bioMérieux, Fransa) ve Render BC128 (Shandong Huifa Electronics Technology Co., Ltd. Çin) tam otomatik kan kültür sistemleri kullanılmıştır. Bakteri identifikasyonu konvansiyonel yöntemler ve Phoenix ${ }^{T M} 100$ otomatize identifikasyon sistemi kullanılarak yapılmıstır. Bakterilerin antibiyotiklere duyarlllik testleri Phoenix ${ }^{T M} 100$ (BD Phoenix System, Beckton Dickinson, ABD) otomatize identifikasyon sistemi ile gerceklestirilmistir.

Toplam 22.786 kan kültürü örneğinden 717'sinde (\% 3,1) Enterobacteriaceae türleri izole edilmiştir. En sık izole edilen tür Escherichia coli (\% 44,7) iken, onu sırasıyla Klebsiella spp. (\% 33,1), Enterobacter spp. $(\% 11,7)$, Serratia marcescens $(\% 4,8)$ ve Proteus spp. $(\% 3,9)$ izlemiştir. izolatların \% 58,7'si yoğun bakım ünitelerinde yatmakta olan hastalardan izole edilmistir. Tarama testlerine göre saptanan genişlemiş spektrumlu beta-laktamaz sıklığı E.coli'de \% 42,5, Klebsiella spp.'de \% 72,6, karbapenem direnci E.coli'de \% 3,1, Klebsiella spp.'de \% 35,4 ve Enterobacter spp.'de \% 10,7 olarak saptanmiştır.

Klebsiella spp. ve E.coli izolatlarında tigesiklin, amikasin ve meropenem etkili ajanlarken diğer ajanlara yüksek direnc oranları saptanmıstır. Klebsiella spp. suslarındaki yüksek direnc ülkemiz verilerinin üzerinde, E.coli suşlarında ise altında kalmıştır. GSBL ve karbapenem direnci ülkemiz verileriyle uyumlu bulunmuştur. Kan kültürlerinden izole edilen bakteri türleri ve antibiyotik duyarlııkları bölgelere ve hastanelere göre farklılıklar göstermektedir. Bu nedenle her merkez kendi etken ve direnç profilini düzenli aralıklarla saptayarak uygun antibiyotik politikalarını oluşturmalıdır.

Anahtar kelimeler: antimikrobiyal direnç, Enterobacteriaceae, genişlemiş spektrumlu betalaktamaz, kan kültürü, karbapenem direnci

\section{ABSTRACT}

Bloodstream infections are one of the most common invasive infections. In this study, we aimed to identify Enterobacteriaceae strains isolated from bloodstream infections and to investigate the antimicrobial susceptibility rates.

Enterobacteriaceae strains isolated from blood cultures of inpatients between June 2017September 2019 were investigated retrospectively. BacT/ALERT 3D (bioMérieux, France) and Render BC128 (Shandong Huifa Electronics Technology Co., Ltd., China) automated blood culture systems was used. Bacterial identification was performed using conventional methods and PhoenixTM 100 automated identification system (BD Phoenix System, Beckton Dickinson, USA). Antimicrobial susceptibility of bacteria was achieved with the PhoenixTM 100 automated identification system (BD Phoenix System, Beckton Dickinson, USA).

Enterobacteriaceae strains were isolated from 717 samples (3.1\%) in 22,786 blood cultures. The most commonly isolated strain was Escherichia coli (44.7\%), followed by respectively Klebsiella spp. (33.1\%), Enterobacter spp. (11.7\%), Serratia marcescens (4.8\%) and Proteus spp. (3.9\%). $58.7 \%$ of the isolates were isolated from patients in intensive care units. The prevalence of extended spectrum beta-lactamase detected by screening tests was $42.5 \%$ in E.coli, $72.6 \%$ Klebsiella spp., carbapenem resistance was $3.1 \%$ in E.coli, $35.4 \%$ in Klebsiella spp., and $10.7 \%$ in Enterobacter spp.

Klebsiella spp. and E.coli isolates were determined to be effective against tigecycline, amikacin and meropenem and high resistance rates to other agents. The high resistance of Klebsiella spp. strains remained above the data of our country while E.coli strains remained below. ESBL and carbapenem resistance were found to be consistent with our country's data. Bacterial species isolated from blood cultures and their antibiotic susceptibility vary according to regions and hospitals. Each center should establish its own agent and resistance profile at regular intervals and establish appropriate antibiotic policies.

Keywords: antimicrobial resistance, blood culture, carbapenem resistance, Enterobacteriaceae, extended spectrum beta-lactamase
Received/Geliș: 19.03.2020 Accepted/Kabul: 16.06.2020 Published Online/Online Yayın: 31.08.2020

Atıf/Cite as: Kula Atik T, Uzun B. Kan kültürlerinden izole edilen Enterobacteriaceae türlerinin antibiyotik duyarlııklarının araştırılması. ANKEM Derg. 2020;34(2):33-40.

Tuğba Kula Atik

Balıkesir Üniversitesi Tıp Fakültesi, Tıbbi Mikrobiyoloji Anabilim Dalı Balıkesir - Türkiye tkulaatik@gmail.com ORCID: 0000-0002-2433-1977

B. Uzun 0000-0001-9115-5910

Izmir Katip Çelebi Üniversitesi Atatürk Eğitim Araştırma Hastanesi Tıbbi Mikrobiyoloji Kliniği izmir - Türkiye 


\section{Giriş}

Gram negatif bakterilerde antibiyotik direnci gün geçtikçe artmakta ve tedavi seçeneklerinin birkaç grup antibiyotikle sınırlı kalmasına neden olmaktadır. Azalan tedavi seçenekleri, çoklu ilaç direncine sahip enterik bakterilerin neden olduğu enfeksiyonları önemli bir sorun haline getirmektedir(16). Betalaktamaz, beta-laktam antibiyotiklerin hidroliziyle bu antibiyotikleri inaktif hale getiren, başta Enterobacteriaceae üyeleri olmak üzere birçok bakteri türünün direnç mekanizmalarındand ${ }^{r(24)}$. Genişlemiş spekturumlu beta-laktamazlar (GSBL) ise beta-laktam antibiyotiklerdeki amid bağlarını parçalayan enzimlerdir ve Enterobacteriaceae ailesi içinde en sık Klebsiella pneumoniae ve Escherichia coli'de bulunmaktadırlar ${ }^{(5,26)}$.

Kan dolaşımı enfeksiyonlarına neden olan Gram negatif enterik çomaklar çoğunlukla çoklu antibiyotik direncine sahiptirler ${ }^{(10,26)}$. Karbapenemlerin GSBL üreten bakteriler ile oluşan ciddi enfeksiyonların tedavisinde yaygın olarak kullanılması, karbapenemaz üreten suşların ortaya çıkmasına neden olmuştur ${ }^{(18)}$. Çeşitli karbapenemlere dirençli Enterobacteriaceae türleri, epidemiyolojik özellikleri ülkeden ülkeye değişse de, dünya üzerinde gittikçe artan bir yayılım göstermektedirler. Karbapenemlere dirençli bu bakterilere bağı enfeksiyonların nasıl tedavi edilecekleri büyük ölçüde belirsiz olup prognozları kötü ve mortaliteleri de oldukça yüksektir(15).

Kan dolaşımı enfeksiyonlarının tedavisinin doğru yönlendirilmesi ve enfeksiyonların kontrolünün sağlanması için klinik izolatlardaki etken mikroorganizmaların antibiyotik direnç paternlerinin her merkez tarafından sürekli olarak takip edilmesi gerekmektedir $^{(24,26,27)}$. Bu nedenle çalışmamızda, kan kültürlerinden izole edilen Enterobacteriaceae türlerinin tanımlanması ve çeşitli antibiyotiklere duyarlıık durumlarının araştırılması amaçlanmıştır.

\section{GEREÇ VE YÖNTEM}

Çalışmamız 900 yatak kapasitesine ve çeşitli branşlarda toplam 19 adet yoğun bakım ünitesine sahip hastanemizin mikrobiyoloji laboratuvarında gerçekleşmiştir. Haziran 2017-Eylül 2019 tarihleri arasında yatan hastalardan gönderilen kan kültürü örneklerinden izole edilen Enterobacteriaceae üyelerinin antibiyotik direnç durumları retrospektif olarak incelenmiştir.

Kan kültürü örnekleri, Haziran 2017-Ağustos 2018 tarihleri arasında BacT/Alert ${ }^{\circledR}$ 3D (bioMérieux, Marcyl'Etoile, Fransa) tam otomatik kan kültür sisteminde, Ağustos 2018-Eylül 2019 tarihleri arasında ise Render BC128 (Shandong Huifa Electronics Technology Co., Ltd., Çin) tam otomatik kan kültür sisteminde beş gün süreyle (Brucella şüphesi bildirilmiş ise yedi gün süreyle) inkübe edilmiştir. Üreme sinyali veren şişelerden Gram boyama yapılmış ve örnekler \% 5 koyun kanlı agar ve eozin metilen mavisi (EMB) agar besiyerlerine ekilerek $37^{\circ} \mathrm{C}^{\prime}$ de $24-48$ saat süresince inkübe edilmiştir. Koloni morfolojisi, Gram boyama, karbonhidrat ve sitrat kullanımı, üreaz üretimi, oksidaz testi gibi konvansiyonel yöntemler ve Phoenix ${ }^{\top M}$ 100 otomatize identifikasyon sistemi (BD Phoenix System, Beckton Dickinson, ABD) kullanılarak tanımlanan Enterobacteriaceae izolatlarının antibiyotik duyarlılıkları EUCAST (European Committee on Antimicrobial Susceptibility Testing) ${ }^{(25)}$ sınır değerlerine göre Phoenix ${ }^{\mathrm{TM}} 100$ otomatize identifikasyon sistemi (BD Phoenix System, Beckton Dickinson, ABD) ile belirlenmiştir. Çalışmamızın bir kısıtııı̆ı olarak GSBL ve karbapenemaz doğrulama testleri yapılamamış, otomatize identifikasyon sisteminden alınan sonuçlara göre olası oranlar bildirilmiştir. Her hastadan izole edilen ilk suş değerlendirmeye alınmıştır.

\section{BULGULAR}

Çalışmanın yapıldığı süre içerisinde laboratuvarımıza 22.786 kan kültürü örneği gönderilmiş, 4.997'sinde (\% 21,9) üreme olmuştur. Üreme olan kan kültürlerinden izole edilen 717 (\% 14,3) Enterobacteriaceae üyesi izolat çalışmaya dahil edilmiştir. İzole edilen Enterobacteriaceae üyelerinin tür düzeyinde dağııımı Tablo 1'de, kliniklere göre dağılımı Tablo 2'de, antibiyotik 
T. Kula Atik ve B. Uzun, Kan Kültürlerinden İzole Edilen Enterobacteriaceae Türlerinin Antibiyotik Duyarlılıklarının Araştırılması

Tablo 1. İzole edilen Enterobacteriaceae üyelerinin cins ve/veya tür düzeyinde dağılımı.

\begin{tabular}{lc}
\hline Mikroorganizma & $\mathbf{n}(\%)$ \\
\hline E.coli & $321(44,7)$ \\
Klebsiella spp. & $238(33,1)$ \\
Enterobacter spp. & $84(11,7)$ \\
Serratia marcescens & $35(4,8)$ \\
Proteus spp. & $28(3,9)$ \\
Citrobacter spp. & $6(0,8)$ \\
Morganella morganii & $5(0,6)$ \\
\hline Toplam & $717(100)$ \\
\hline
\end{tabular}

direnç durumları ise Tablo 3'te verilmiştir. Tarama testlerine göre saptanan GSBL pozitiflik oranı E.coli için \% 42,5 (134/315), Klebsiella spp. için ise \% 72,6 (170/234) olarak bulunmuştur. Ayrıca E.coli'de \% 3,1
(10 suş), Klebsiella spp.'de \% 35,4 (84 suş) ve Enterobacter spp.'de \% 10,7 (9 suş) izolatta meropenem direnci saptanmıştır.

\section{TARTIŞMA}

Yüksek morbidite ve mortalite ile ilişkili olan bakteriyemi, yoğun bakım üniteleri gibi yüksek riskli alanlarda yatan hastalar için büyük bir risk faktörüdür ${ }^{(12)}$. Bakteriyemilere sebep olan mikroorganizmaların tanımlanmasında en önemli aşama kan kültürleri olup otomatize sistemlerle etken mikroorganizmalar ve direnç profilleri kısa sürede tespit edilebilmektedir $^{(11)}$. Çalışmamızda kan kültürlerindeki pozitiflik oranı \% 21,9 bulunmuştur. Farkı hasta

Tablo 2. İzole edilen Enterobacteriaceae üyelerinin tür düzeyinde kliniklere göre dağılımı [n (\%)].

\begin{tabular}{|c|c|c|c|c|}
\hline Mikroorganizma & $\begin{array}{c}\text { Yoğun Bakım Üniteleri } \\
\text { n (\%) }\end{array}$ & $\begin{array}{c}\text { Dahili Servisler } \\
\text { n (\%) }\end{array}$ & $\begin{array}{c}\text { Cerrahi Servisler } \\
\text { n (\%) }\end{array}$ & $\begin{array}{c}\text { Toplam } \\
\text { n (\%) }\end{array}$ \\
\hline E.coli & $141(16,9)$ & $150(20,9)$ & $30(4,1)$ & $321(44,7)$ \\
\hline Klebsiella spp. & $191(26,6)$ & $36(5,0)$ & $11(1,5)$ & $238(33,1)$ \\
\hline Enterobacter spp. & $42(5,8)$ & $40(5,5)$ & $2(0,2)$ & $84(11,7)$ \\
\hline Serratia marcescens & $21(2,9)$ & $12(1,6)$ & $2(0,2)$ & $35(4,8)$ \\
\hline Proteus spp. & $21(2,9)$ & $7(0,9)$ & 0 & $28(3,9)$ \\
\hline Citrobacter spp. & $2(0,2)$ & $4(0,5)$ & 0 & $6(0,8)$ \\
\hline Morganella morganii & $3(0,4)$ & $2(0,2)$ & 0 & $5(0,6)$ \\
\hline Toplam & $421(58,7)$ & $251(35,0)$ & $45(6,2)$ & $717(100)$ \\
\hline
\end{tabular}

Tablo 3. İzole edilen Enterobacteriaceae üyelerinin tür düzeyinde antibiyotik direnç oranları*.

\begin{tabular}{|c|c|c|c|c|c|c|}
\hline \multirow[b]{2}{*}{ Antibiyotik } & \multicolumn{2}{|c|}{$\begin{array}{l}\text { E.coli } \\
(321)\end{array}$} & \multicolumn{2}{|c|}{$\begin{array}{c}\text { Klebsiella spp. } \\
\text { (238) }\end{array}$} & \multicolumn{2}{|c|}{$\begin{array}{l}\text { Enterobacter spp. } \\
\text { (84) }\end{array}$} \\
\hline & $\mathbf{n}$ & $\%$ & $\mathbf{n}$ & $\%$ & $\mathbf{n}$ & $\%$ \\
\hline Ampisilin & $215 / 317$ & 67,8 & $234 / 234$ & DD & $83 / 83$ & $\mathrm{DD}$ \\
\hline Amoksisilin/ klavulanik asit & $170 / 317$ & 53,6 & $180 / 233$ & 77,2 & $83 / 83$ & $\mathrm{DD}$ \\
\hline Amikasin & 4/309 & 1,2 & $69 / 237$ & 29,1 & $2 / 80$ & 2,5 \\
\hline Gentamisin & $108 / 321$ & 33,6 & $134 / 238$ & 56,3 & $12 / 84$ & 14,2 \\
\hline Netilmisin & $96 / 301$ & 31,8 & $127 / 219$ & 57,9 & $9 / 80$ & 11,2 \\
\hline Sefuroksim & $148 / 300$ & 49,3 & $165 / 222$ & 74,3 & $83 / 83$ & DD \\
\hline Seftriakson & $138 / 315$ & 43,8 & $170 / 234$ & 72,6 & $24 / 82$ & 29,2 \\
\hline Seftazidim & $134 / 317$ & 42,2 & $170 / 236$ & 72 & $19 / 83$ & 22,8 \\
\hline Sefepim & $130 / 320$ & 40,6 & $166 / 234$ & 70,9 & $20 / 84$ & 23,8 \\
\hline Siprofloksasin & $148 / 320$ & 46,2 & $150 / 234$ & 64,1 & $13 / 83$ & 15,6 \\
\hline Ertapenem & $30 / 303$ & 9,9 & $118 / 228$ & 51,7 & $13 / 81$ & 16 \\
\hline İmipenem & 4/321 & 1,2 & $82 / 238$ & 34,4 & $6 / 84$ & 7,1 \\
\hline Meropenem & $10 / 319$ & 3,1 & $84 / 237$ & 35,4 & $9 / 84$ & 10,7 \\
\hline Piperasilin & $215 / 317$ & 67,8 & $234 / 234$ & 100 & $22 / 81$ & 27,1 \\
\hline Piperasilin/tazobaktam & $42 / 321$ & 13 & $140 / 236$ & 59,3 & $17 / 82$ & 20,7 \\
\hline Trimetoprim/sülfametoksazol & $147 / 309$ & 47,5 & $114 / 230$ & 49,5 & $14 / 82$ & 17 \\
\hline Tigesiklin & $4 / 290$ & 1,3 & $25 / 215$ & 11,6 & $6 / 79$ & 7,5 \\
\hline Aztreonam & $124 / 307$ & 40,3 & $160 / 228$ & 70,1 & $20 / 83$ & 24 \\
\hline
\end{tabular}

*Devamı arka sayfadadır. 
Tablo 3 (devam). İzole edilen Enterobacteriaceae üyelerinin tür düzeyinde antibiyotik direnç oranları.

\begin{tabular}{|c|c|c|c|c|c|c|c|c|}
\hline \multirow[b]{2}{*}{ Antibiyotik } & \multicolumn{2}{|c|}{$\begin{array}{c}\text { Serratia marcescens } \\
\text { (35) }\end{array}$} & \multicolumn{2}{|c|}{$\begin{array}{l}\text { Proteus spp. } \\
\text { (28) }\end{array}$} & \multicolumn{2}{|c|}{$\begin{array}{c}\text { Citrobacter spp. } \\
\text { (6) }\end{array}$} & \multicolumn{2}{|c|}{$\begin{array}{c}\text { Morganella morgani } \\
\text { (5) }\end{array}$} \\
\hline & $\mathbf{n}$ & $\%$ & $\mathbf{n}$ & $\%$ & $\mathbf{n}$ & $\%$ & $\mathbf{n}$ & $\%$ \\
\hline Ampisilin & $35 / 35$ & DD & $19 / 25$ & 76 & $6 / 6$ & $\mathrm{DD}$ & $5 / 5$ & DD \\
\hline Amoksisilin/ klavulanik asit & $33 / 33$ & $\mathrm{DD}$ & $4 / 27$ & 14,8 & $6 / 6$ & $\mathrm{DD}$ & $5 / 5$ & DD \\
\hline Amikasin & - & - & $4 / 27$ & 14,8 & - & - & - & - \\
\hline Gentamisin & $3 / 35$ & 8,5 & $8 / 28$ & 28,5 & $2 / 6$ & 33,3 & - & - \\
\hline Netilmisin & $11 / 32$ & 34,3 & $8 / 27$ & 29,6 & - & - & $2 / 5$ & 40 \\
\hline Sefuroksim & $33 / 33$ & $\mathrm{DD}$ & $7 / 18$ & 38,8 & $6 / 6$ & DD & $5 / 5$ & $\mathrm{DD}$ \\
\hline Seftriakson & $5 / 35$ & 14,2 & $13 / 26$ & 50 & - & - & $2 / 5$ & 40 \\
\hline Seftazidim & $2 / 33$ & 6 & $2 / 27$ & 7,4 & - & - & $2 / 5$ & 40 \\
\hline Sefepim & $4 / 35$ & 11,4 & $3 / 27$ & 11,1 & - & - & - & - \\
\hline Siprofloksasin & - & - & $10 / 28$ & 35,7 & $2 / 6$ & 33,3 & $2 / 5$ & 40 \\
\hline Ertapenem & - & - & $4 / 25$ & 16 & - & - & - & - \\
\hline İmipenem & $3 / 35$ & 8,5 & $16 / 16$ & DD & - & - & $5 / 5$ & DD \\
\hline Meropenem & - & - & - & - & - & - & - & - \\
\hline Piperasilin & $4 / 33$ & 12,1 & $19 / 25$ & 76 & & & & \\
\hline Piperasilin/tazobaktam & - & - & - & - & - & - & - & - \\
\hline Trimetoprim/sülfametoksazol & - & - & $11 / 26$ & 42,3 & $2 / 6$ & 33,3 & $3 / 5$ & 60 \\
\hline Tigesiklin & $35 / 35$ & 100 & $28 / 28$ & $\mathrm{DD}$ & - & - & $5 / 5$ & 100 \\
\hline Aztreonam & $2 / 32$ & 6,2 & $3 / 26$ & 11,5 & - & - & - & - \\
\hline
\end{tabular}

n: Dirençli izolat sayısı/Çalışılan izolat sayısı (\%), DD: Doğal direnç

kapasitelerine sahip hastanelerde farklı kan kültürü pozitifliği oranları ile karşılaşılabilmektedir ${ }^{(7,12,21)}$.

Kan kültürü örneklerinin gönderildiği klinikler değerlendirildiğinde; kan kültürü pozitifliğinin daha sıklıkla dahili kliniklerde yatan hastalardan izole edildiği çalışmalar bildirilmekle birlikte ${ }^{(3,12,21)}$ daha sıklıkla yoğun bakım ünitelerinden gelen örneklerden izole edildiği çalışmalar da izlenmektedir ${ }^{(3,17,20)}$. Aynı şekilde kan kültürlerinden izole edilen Gram negatif bakterilerin önemli bir kısmının yoğun bakım ünitelerinde tedavi gören hastalardan izole edildiğ bildirilmektedir ${ }^{(11)}$. Yirmi dört ülkeyi kapsayan uluslararası bir kohort çalışmasında, yoğun bakım ünitelerinde hastane kaynaklı bakteriyemilerden daha sıklıkla Gram negatif bakterilerin (\% 58,3) izole edildiği belirtilmiştir ${ }^{(23)}$. Çalışmamızda Gram negatif Enterobacteriaceae izolatlarının \% 58,7'sinin yoğun bakım ünitelerinde, \% 35'inin dahili servislerde ve $\%$ 6,2'sının cerrahi servislerde tedavi gören hastalardan izole edildiği görülmüştür. Yoğun bakım ünitelerinde yatan hastalara, servislerde yatan hastalara kıyasla daha fazla invaziv girişimlerin uygulanması, bu hastalara yoğun ve geniş spektrumlu antibiyotiklerin sıklıkla kullanılması ve bir kısım hastanın immün baskılanmış olmasının bu enfeksiyonların yoğun bakım ünitelerinde fazla görülmesine sebep olduğu düşünülmüştür.

Ülkemizde kan dolaşımı enfeksiyonlarına neden olan Gram negatif bakteriler içinde E.coli ilk sıralarda bulunmaktadır ve görülme sıklığı \% 5,7-13'tür ${ }^{(3,12,20,22) .}$ Çalışmamızda Enterobacteriaceae üyelerinden en sıklıkla E.coli (\% 44,7) ve Klebsiella spp. (\% 33,1) izole edilmiştir. Tür düzeyinde diğer Enterobacteriaceae üyeleri sırasıyla, Enterobacter spp., Serratia marcescens, Proteus spp., Citrobacter spp. ve Morganella morganii şeklindedir. Kan kültürlerinden izole edilen tüm Gram negatif etkenleri inceleyen çalışmalarda ${ }^{(24)}$ benzer şekilde en sıklıkla E.coli $(\% 37,7)$ ve Klebsiella pneumoniae $(\% 22,6)$ izole edilmiştir. Kan kültürlerinden izole edilen mikroorganizmaları inceleyen çalışmalarda Gram negatif etkenler \% 18,9-39,0 oranlarında saptanırken, Gram negatif etkenler içerisinde sırasıyla E.coli \% 20-57,5, Klebsiella spp. \% 10,2-26,2 oranlarında bildirilmiştir ${ }^{(20,21,22)}$. İzole edilen etkenlerin dağııımı hastane tipine ve büyüklüğüne, bakteriyemilerin hastane veya toplum kökenli olmasına, bakteriyemilerin kateterle ilişkisine, uygulanan antibiyotik tedavi protokollerine bağlı olarak değişiklik gösterebilmektedir ${ }^{(20)}$. 
GSBL üreten bakterilerin neden olduğu enfeksiyonlar, karbapenemlerin bu bakterilerle oluşan ciddi hastalıkların tedavisinde son savunma hattı olarak tercih edilmesine ve dolayısıyla karbapenemaz üreten suşların ortaya çıkmasına neden olduğu bilinmektedir. Karbapenemaz üretimi GSBL üretiminde olduğu gibi Enterobacteriaceae izolatlarında sıklıkla K.pneumoniae ve E.coli türlerinde görülmektedir(6). Karbapenemaz ve GSBL varlığının rutinde test edilmesi önerilmemekte ancak, enfeksiyon kontrolü ve epidemiyolojik verilerin toplanması için gerekli olduğu belirtilmektedir ${ }^{(26)}$. Güncellenen yeni sınır değerlere göre klinik izolatlarda rutin antibiyogram testleri sırasında bu direnç enzimlerinin belirlenmesine gerek olmasa da laboratuvarların olanaklarına göre belirlenmesi ve enfeksiyon kontrol çalışmalarına destek olunması kıymetlidir. Çalışmamızda tarama testlerine göre saptanan GSBL pozitiflik oranı, E.coli izolatlarında \% 42,5, K.pneumoniae izolatlarında \% 72,6 oranında saptanmıştır. Hітіт çalışmalarında ülkemizde GSBL sıklığı E.coli ve K.pneumoniae izolatlarında sırasıyla \% 32-42 ve \% 33-41 olarak bildirilmiştir ${ }^{(8,9)}$. Sonraki yıllarda ülkemizden bildirilen bazı çalışmalarda GSBL pozitiflik oranı E.coli için \% 14 ve K.pneumoniae için \% 21 olarak oldukça düşük saptanırken ${ }^{(21)}$; sırasıyla Karaayak ve ark. ${ }^{(10) ' n ı n}$ \% 32 ile \% 38, Küçükateş ve ark. (12)'nın \% 40 ile \% 60, Şafak ve ark. ${ }^{(20) ' n ı n ~ \% ~} 49$ ile \% 69,9 oranlarında saptanan bazı çalışmalarda olduğu gibi yıllar içerisinde artan oranlarda bildirilmiştir. Çalışmamızda saptadığımız yüksek oranlar, yıllar içerisinde ülkemizdeki GSBL üreten suşların sıklığının ne kadar çok arttığını göstermesi bakımından dikkat çekicidir.

Çalışmamızda karbapenem direnci E.coli'de \% 3,1, Klebsiella spp.'de \% 35,4 ve Enterobacter spp.'de \% 10,7 oranında saptanmış, diğer Enterobacteriaceae üyelerinde direnç saptanmamıştır. Klebsiella spp. suşlarındaki yüksek direnç ülkemiz verilerinin üzerinde kalırken, E.coli suşlarında ise ülkemiz verilerine göre daha düşük bulunmuştur. Ülkemizde 2012, 2013 ve 2014 yıllarında gerçekleştirilen çalışmalarda E.coli ve K.pneumoniae izolatlarında karbapenem direnci saptanmazken sonraki yıllarda bildirilen çalış- malarda yıllar içerisinde artan direnç oranlarına rastlanmıştır ${ }^{(10,21,24)}$. Karbapenem direncini K.pneumoniae için Er ve ark. ${ }^{(3)} \%$ 3,7 saptarken; E.coli ve K.pneumoniae için sırasıyla Kılıç ve ark. ${ }^{(11)} \% 8,1$ ve $\%$ 3,6, Küçükateş ve ark. ${ }^{(12)} \% 18$ ve \% 12,5, Say Coşkun ve ark.(17) \% 4,7 ve \% 31,5 olarak saptamışlardır. Ayrıca Say Coşkun ve ark. ${ }^{(17)}$ Enterobacter spp.'de meropenem ve imipenem direncini \% 23,1 ile \% 15,3 olarak saptarken; Proteus spp.'de ise meropenem direnci saptamamışlardır. Нітіт surveyans çalışmasında E.coli izolatlarında imipeneme direnç saptanmazken, K.pneumoniae'de imipenem direnci \% 1,3 olarak bulunmuştur ${ }^{(8)}$. Central Asian and Eastern European Surveillance on Antimicrobial Resistance (CAESAR) 2015 yılı verilerine göre karbapenemlere karşı Gram negatif bakterilerde direnç oranlarının diğer antibiyotiklere göre daha düşük olduğu görülmektedir. Karbapenem direnci E.coli için \% 2, K.pneumoniae için \% 30 olarak bildirilmiştir(2). Çalışmamızda S.marcescens suşlarında karbapenem direnci saptanmazken ülkemizden direnç $(\% 8,7)$ bildirilmiştir(22). ABD ve Avrupa ülkelerini kapsayan çok merkezli bir çalışmada, yoğun bakım ünitelerinden izole edilen S.marcescens suşlarında imipenem direnci \% 7,2 olarak gözlemlenmiştir ${ }^{(19)}$. Çalışmamızda hem tarama testlerine göre saptanan GSBL pozitiflik oranında hem de karbapenem direncinde saptanan oldukça yüksek oranlar son yıllardaki ülkemiz direnç verileriyle uyumlu olmakla birlikte izolatlarımızın çoğunun yoğun bakım ünitelerinde yatan hasta örneklerinden elde edilmiş olması ile ilişkilendirilmiştir.

Aminoglikozid modifiye edici enzimlerden daha az etkilendiği için, aminoglikozid grubunun diğer üyelerine kıyasla amikasine karşı daha nadir direnç gelişmektedir ${ }^{(28)}$. Central Asian and Eastern European Surveillance on Antimicrobial Resistance (CAESAR) çalışması verilerine göre Gram negatif bakterilerde aminoglikozid direnç oranları E.coli için \% 28, K.pne umoniae için \% 44 olarak çalışmamızdan oldukça yüksek bildirilmiştir(19). Çalışmamızda gentamisin, Enterobacter spp., S.marcescens ve Morganella morgani için etkin iken netilmisin ise Enterobacter spp. ve Citrobacter spp. için etkin olarak tespit edilmiştir. 
Amikasin ise Klebsiella spp. suşları dışında tüm Enterobacteriaceae izolatlarına karşı oldukça etkin olup Klebsiella spp. suşlarında kullanılabilecek ikinci ajan olarak bulunmuştur. Asya ülkelerinden bildirilen SMART çalışmasında amikasin (\% 8 direnç oranı) E.coli ve K.pneumoniae izolatlarına karşı en etkili antibiyotik olarak bulunmuştur ${ }^{(13)}$. Afrika'dan bildirilen SMART çalışmasında K.pneumoniae izolatlarında amikasine karşı yine \% 8 direnç saptanırken, amikasin ertapenemden sonra etkin ikinci antibiyotik olarak bildirilmiştir ${ }^{(1)}$. Amikasin direncini E.coli ve K.pneumoniae izolatlarında Kılıç ve ark. ${ }^{(11)} \% 7$ ile \% 39,6, Küçükateş ve ark. ${ }^{(12)} \% 18$ ile \% 25, Şafak ve ark. ${ }^{(20)} \%$ 2,5 ile \% 5,5, Şirin ve ark. ${ }^{(22)} \%$ 6,2 ile \% 24,1, Say Coşkun ve ark. ${ }^{(17)} \% 3.8$ ile \% 9.6 olarak saptamışlardır. Temiz ve ark. ${ }^{(24)}$ E.coli ve K.pneumoniae için \% 47,6 ile \% 45 direnç saptarken, Enterobacter spp. için dirençli suş saptamamışlardır. Amikasin hastanemiz izolatları için oldukça etkindir. Ancak aminoglikozidler in-vitro duyarlı bulunsalar bile ciddi enfeksiyonlarda tek başına kullanılmamaları gerektiği unutulmamalıdır ${ }^{(10)}$.

Tigesiklin direnci E.coli'de \% 1,3, K.pneumoniae'da \% 11,6 ve Enterobacter spp.'de \% 7,5 saptanmıştır. Proteus spp.'nin tigesikline doğal dirençli, S.marcescens ve Morganella spp.'nin ise düşük tigesiklin duyarlııı̆ı ile ${ }^{(14)}$ uyumlu olarak çalışmamızdaki bu izolatlar tigesikline dirençli bulunmuşlardır. Citrobacter spp. izolatlarına direnç saptanmamıştır. Dirençli izolatlarda kullanııması önerilen bu ajana karşı da direnç saptanmış olması tigesiklinin hastanemizde daha dikkatli kullanılması gerektiğini vurgulamıştır.

Karbapenemaz pozitif kökenlerde, karbapenemler, penisilinler ve sefalosporinlere direnç gelişmekte, beraberinde aminoglikozidler, florokinolonlar ve trimetoprim-sülfametoksazole direnç mekanizmalarını kodlayan genler de taşınmaktadır ${ }^{(4)}$. Çalışmamızda Enterobacter spp. ve S.marcescens suşları dışındaki tüm izolatlarda kinolon ve trimetoprimsülfametoksazol direnci \% 33 ve üzerinde oranlarda saptanmıştır. Ülkemizde farklı çalışmalarda siprofloksasin ve trimetoprim-sülfametoksazol direncinin değişen oranlarda olduğu görülmüştür ${ }^{(21,24)}$.
Çalışmamızda S.marcescens, Proteus spp., Citrobacter spp. ve Morganella morgani suşlarında sefalosporinlere ve monobaktamlara düşük direnç saptanması ya da hiç direnç saptanmaması nedeniyle bu ajanların oldukça etkin antimikrobiyaller olduğu düşünülmüştür. Ayrıca bu etken mikroorganizmalarda karbapenem direnci saptanmamıştır. Ülkemizdeki çalışmalardan daha düşük oranlarda ${ }^{(17,22)}$ direnç saptanması bu ajanların hastanemizde uygulanan kısıtlı antibiyotik bildirimlerine ve uygulamalarına bağlanmıştır. Beta-laktam/beta-laktamaz inhibitörü kombinasyonları tedavi alternatifleri arasında yer almasına karşın, bu grup ilaçlarla tedavi başarısızIıklarıyla karşılaşılabilmektedir(10). Temiz ve ark. ${ }^{(24)}$ E.coli ve K.pneumoniae suşlarında piperasilintazobaktam direncini $\% 76,2$ ve $\% 65$, Karaayak ve ark. ${ }^{(10)} \% 50$ ve $\% 62$ oranlarında bulmuşlardır. Нітіт surveyans çalışmasında ${ }^{(9)}$ sırasıyla $\% 10$ ve $\% 22$ olarak belirlenmiştir. Çalışmamızda amoksasilinklavulanik asit Proteus spp. suşlarında etkinken diğer suşlarda etkisiz bulunmuş, piperasilin-tazobaktam ise Klebsiella spp. suşları dışında oldukça etkin bir ajan olarak tespit edilmiştir. Çalışmamızda saptadığımız direnç oranları ülkemiz verileriyle uyumludur.

Etken mikroorganizmalara göre özetlersek, Klebsiella spp. izolatlarında tigesiklin en etkili ajan iken, tarama testlerine göre saptanan GSBL pozitiflik oranı $\% 72,6$ ve karbapenem direnci \% 35,4 ile oldukça yüksektir. Özellikle 3. ve 4. kuşak sefalosporinlere ve monobaktamlara karşı çok yüksek direnç saptanmıştır. Amikasin direnci \% 29,1'lik oran ile diğer ajanlara göre göreceli olarak düşük gözlenmiştir. E.coli izolatlarında amikasin, tigesiklin ve karbapenemler etkin ajanlardır. Tarama testlerine göre saptanan GSBL pozitiflik oranı \% 42,5 ile yüksek oranda tespit edilmiştir. Diğer antimikrobiyallere direnç ise Klebsiella spp. izolatları kadar olmasa da yüksek bulunmuştur. Enterobacter spp. izolatlarında \% 10,7 karbapenem direnci gözlenmiştir. Enterobacter spp. izolatlarına karşı da en etkin ajan olarak tigesiklin ve aminoglikozidler tespit edilmiş, ayrıca diğer ajanların da etkili olduğu saptanmıştır. Sonuç olarak, GSBL aktarımı plazmid ve transpozon aracılığıyla olmakta 
ve GSBL üreten suşlar diğer antibiyotiklere karşı da direnç oluşmasına katkıda bulunmaktadır. Bu nedenle çalışmamız, hastanemizde enfeksiyon koruma önlemlerinin gözden geçirilmesi ve var olan önlemlerin arttırılması gerektiğini göstermektedir. Ayrıca belirli aralıklarla direnç verilerinin gözden geçirilmesi ve uygulanmakta olan kısıtlı antibiyotik bildirimleri uygulamalarının devamlılığının sağlanması gerektiği sonuçlarına varılmıştır.

Çıkar Çatışması: Yazarlar tarafından herhangi bir çıkar çatışması bildirilmemiştir.

Conflict of Interest: No conflict of interest was declared by the authors.

\section{KAYNAKLAR}

1. Brink AJ, Botha RF, Poswa X, et al. Antimicrobial susceptibility of gram negative pathogens isolated from patients with complicated intra-abdominal infections in South African hospitals (SMART Study 2004-2009): impact of new carbapenem breakpoints. Surg Infect. (Larchmt). 2012;13(1):43-9.

2. Central Asian and Eastern European Surveillance of Antimicrobial Resistance CAESAR Annual Report 2016: http: www.euro.who.int/en/health-topics/ disease-prevention/antimicrobial-resistance/ publications/2016/central-asian-and-eastern european-surveillance-of-antimicrobialresistance.annual-report-2016.

3. Er H, Aşık G, Yoldaş Ö, Demir C, Keşli R. Kan kültürlerinde izole edilerek tanımlanan mikroorganizmaların ve antibiyotik direnç oranlarının belirlenmesi. Turk Mikrobiyol Cemiy Derg. 2015;45(1):48-54.

4. Falagas ME, Bliziotis IA, Kasiakou SK, Samonis G, Athanassopoulou $P$, Michalopoulos A. Outcome of infections due to pandrug-resistant (PDR) gramnegative bacteria. BMC Infect Dis. 2005;5:24.

5. Falagas ME, Karageorgopoulos DE. Extendedspectrum beta-lactamase-producing organisms, J Hosp Infect. 2009;73(4):345-54.

6. Gulmez D, Woodford N, Palepou MFI, et al. Carbapenem-resistant Escherichia coli and Klebsiella pneumoniae isolates from Turkey with OXA-48-like carbapenemases and outer membrane protein loss. Int J Antimicrob Agents. 2008;31(6):523-6.

7. Güngör S, Karaayak Uzun B, Gül Yurtsever S, Baran N.
Kan kültürlerinden izole edilen Staphyloccocus aureus suşlarında antibiyotiklere direnç. ANKEM Derg. 2012;26(4):171-5.

8. Gür D, Gülay Z, Arıkan Akan Ö, ve ark. Türkiye'de hastane izolatı gram negatif bakterilerde yeni betalaktam antibiyotiklere direnç ve GSBL tipleri: çok merkezli Hітіт sürveyansının sonuçları. Mikrobiyol Bul. 2008;42(4):537-44.

9. Gür D, Hascelik G, Aydin N, et al. Antimicrobial resistance in gram-negative hospital isolates: results of the Turkish HITIT-2 Surveillance Study of 2007. J Chemother. 2009;21(4):383-9.

10. Karaayak Uzun B, Gungor S, Şerifhan ilgun $M$, Ozdemir R, Baran N, Yuksel Ergin O. Kan kültürlerinden izole edilen Escherichia coli ve Klebsiella pneumoniae izolatlarında genişlemiş spektrumlu beta-laktamaz sıklığı ve in-vitro antibiyotiklere direnç paternleri. ANKEM Derg. 2012;26(4):181-6.

11. Kılıç Ç, Güçkan R, Kahveci $M$, Kayhan $Y$, Pirhan $Y$, Özalp T. Kan kültürlerinde üreyen gram negatif izolatların dağılımı ve antibiyotik direnç profilleri. Int J Basic Clin Med. 2015;3(3):125-30.

12. Küçükateş $E$, Gültekin N. Yoğun bakım ünitelerinde yatan hastaların kan kültürlerinden izole edilen mikroorganizmalar ve antimikrobiyal duyarlılıkları. Med Bull Haseki. 2016;54(2):97-102.

13. Lu PL, Liu YC, Toh HS, et al. Epidemiology and antimicrobial susceptibility profiles of gram negative bacteria causing urinary tract infections in Asia Pacific region: 2009-2010 results from the study for monitoring antimicrobial resistance trends (SMART). Int J Antimicrob Agents. 2012;40(1):37-43.

14. Milatovic D, Schmitz FJ, Verhoef J, Fluit AC. Activities of the glycylcycline tigecycline (GAR-936) against 1,924 recent European clinical bacterial isolates. J Antimicrobial Agents and Chemother. 2003;47(1): 400-4.

15. Morrill HJ, Pogue JM, Kaye KS, LaPlante KL. Treatment options for carbapenem-resistant Enterobacteriaceae infections. Open Forum Infect Dis. 2015;2(2):ofv050.

16. Nordmann P, Naas T, Poirel L. Global spread of carbapenemase-producing Enterobacteriaceae. Emerg Infect Dis. 2011;17(10):1791-8.

17. Say Coşkun US. Kan kültürlerinden üreyen mikroorganizmalar ve antibiyotik duyarlılıkları. ANKEM Derg. 2018;32(2):45-52.

18. Swaminathan M, Sharma S, Poliansky Blash S, et al. Prevalence and risk factors for acquisition of carbapenem resistant Enterobacteriaceae in the setting of endemicity. Infect Control Hosp Epidemiol. 2013;34(8):809-8.

19. Sader HS, Farrell DJ, Flamm RK, et al. Antimicrobial susceptibility of Gram negative organisms isolated 
from patients hospitalized in intensive care units in United States and European hospitals (2009-2011). Diagn Microbiol Infect Dis. 2014;78(4):443-8.

20. Şafak B, Kılınç O. 2010-2015 yılları arasında kan kültürlerinde üreyen mikroorganizmalar ve antibiyotik duyarlılıkları. Klimik Derg. 2016;29(2):60-4.

21. Şahin I, Çalışkan E, Öztürk E, ve ark. Kan kültürlerinden izole edilen mikroorganizmaların dağılımı ve antimikrobiyal duyarlılıkları. Düzce Tıp Derg. 2013;15(2):11-4.

22. Şirin $M C$, Ağuş N, Yılmaz N, ve ark. Yoğun bakım ünitelerinde yatan hastaların kan kültürlerinden izole edilen mikroorganizmalar ve antibiyotik duyarlılıkları. Turk Hij Den Biyol Derg. 2017;74(3):269-78.

23. Tabah A, Koulenti D, Laupland K, et al. Characteristics and determinants of outcome of hospital-acquired bloodstream infections in intensive care units: the EUROBACT international cohort study. Intensiv Care Med. 2012;38(12):1930-45.

24. Temiz H, Temiz S, Kaya Ş, Çelen MK. Kan kültürlerinden izole edilen gram negatif bakterilerde antibiyotik direnci. Klimik Derg. 2014;27(2):62-8.

25. The European Committee on Antimicrobial Susceptibility Testing. Breakpoint tables for interpretation of MICs and zone diameters. Version 9.0, 2019. http://www.eucast.org

26. Topkaya Eren A, Aydın Kurç Mine, Tombak Ö, Gülen D. Kan kültürlerinde üreyen Enterobactericea izolatlarında genişlemiş spektrumlu beta-laktamaz ve karbapenemaz varlığının araştırılması. Namık Kemal Tıp Derg. 2018;6(3):88-95.

27. Uzun B, Güngör S, Sezak N, Afşar I, Şerifhan İlgün $M$, Demirci $M$. Changes in resistance percentage to antibiotics in Pseudomonas aeruginosa and Acinetobacter baumannii strains isolated from blood cultures of intensive care unit patients. Turk Hij Den Biyol Derg. 2014;71(1):1-8.

28. Uzun B, Güngör S, Yurtsever S, Afşar I, Demirci M. Yoğun bakım hastalarının kan kültürlerinden izole edilen Pseudomonas aeruginosa ve Acinetobacter baumannii suşlarının çeşitli antibiyotiklere direnç durumları. ANKEM Derg. 2012;26(2):55-60. 